\title{
The impact of sustainability orientation on firm propensity to ally ${ }^{1}$
}

\section{Stefano Romito - Angeloantonio Russo - Clodia Vurro}

\begin{abstract}
Purpose of the paper: The aim of this paper is to analyse the effect of firm sustainability orientation, defined as the overall proactive strategic stance of firms toward the integration of environmental and social concerns and practices into their strategic and operational activities, on its propensity of making alliances.

Methodology: We validate our arguments using panel data on 10.509 unique firm-year observations over the period 2003-2017.

Findings: We find support for our baseline hypothesis: sustainability orientation has a positive impact on alliance formation. Additionally, we find that the hypothesized relationship is stronger for firms with lower expected value creation and for those that operate in opaque contexts.

Research limits: Our work represents an initial attempt to investigate the role of firm sustainability orientation in explaining firm alliance propensity. In so doing, we adopted a firm level perspective assuming alliance counterparts to be homogeneous, which represents the main limitation of this study. Other limitations, as well as topics for future research are discussed in the last section.

Practical implications: Our arguments and findings emphasize the critical role played by the way in which the firm manages the network of relationships in which it is embedded, in addition to the considerations about the type of relationship a firm owns that have been widely analysed. In particular, our study contributes to obtain a deeper understanding of the benefits of a stakeholder-oriented approach, which remains fundamental to encourage managers to adopt stakeholder theory practices in their behaviour.

Originality of the paper: To the best of our knowledge, this study represents the first attempt to study the relationship between firm sustainability orientation and its alliance propensity.
\end{abstract}

Key words: sustainability orientation; alliance formation; stakeholder management

\section{Introduction}

While many firms rush to jump on the bandwagon of strategic alliances to leverage complementarities or defray costs, only few succeed to achieve expected outcomes. Limited attractiveness because of perceived exchange related risks (Hitt et al., 2000; Russo et al., 2019) and inadequate alliance management capabilities (Wang and Rajagopalan, 2015) are among the

The authors equally contributed to the design and implementation of the research, to the analysis of the results and to the writing of the manuscript, and are listed in alphabetical order. 
sinergie Vol. 39, Issue 2, 202

key reasons that derail firms from alliance formation. Indeed, research and practice have long investigated how the development of valuable resources (Lavie and Rosenkopf, 2006), the availability of information on prospective partners (Luo, 2007), and the active engagement in activities that stimulate partnering skills (Zollo et al., 2002) can support firms in the decision to ally.

In the mainframe of what drives firm's attractiveness as an alliance partner, the role of sustainability orientation, defined as the overall proactive strategic stance of firms towards the integration of environmental and social concerns and practices into their strategic and operational activities (Roxas and Coetzer, 2012), has been mostly neglected. Previous research has largely documented that sustainability orientation is an important driver for the development of innovative capabilities that could easily attract a prospective partner (Carayannopoulos and Auster, 2010). Moreover, the long term attitude of sustainability oriented firms act as a signal that increase their perceived trustworthiness (Parmar et al., 2010). Similarly, the increased availability of information, both directly disclosed and sourced from third parties, about sustainability oriented firms reduces opacity, which, in turn, mitigates the perceived risk of adverse selection (Cho et al., 2013; Cui et al., 2018). Finally, sustainability-oriented firms develop collaborative capabilities with stakeholders that predispose them to cope with situations of higher risk of moral hazard (Russo et al., 2018). Taken together these arguments support the need for further research on the existence of a positive effect of firm sustainability orientation on alliance formation.

Heeding the call for a deeper understanding of what drives the choice of an alliance partner and building on recent advancements on the relevance and role of sustainability orientation (Cheng, 2020; Eccles et al., 2014), we aim at advancing this stream of research by submitting that sustainabilityoriented firms are also different in terms of attractiveness as an alliance partner and ability to form and mange strategic alliances, resulting in a greater propensity to ally. We test our hypotheses using a comprehensive panel dataset of 10.509 unique firm-year observations drawn from USlisted firms over the period from 2003 to 2017. We find support for the notion that sustainability orientation significantly increases the propensity of a firm to form strategic alliances. Moreover, we find evidence that the positive effect of a firm sustainability orientation on its alliance propensity is stronger only for those firms that show characteristics that are commonly associated to a lower attractiveness (i.e., when the financial market does not acknowledge a high potential for value creation and when the risk related to adverse selection is higher because of increased opacity).

The reminder of the paper is structured as it follows. First, earlier research focused on the reasons that derail firms from forming alliances and on the different factors that can support firms in overcoming obstacles is recapitulated. Second, the theoretical framework and hypotheses are developed. These sections are followed by the empirical analysis. Finally, the findings and contributions are discussed, as well as the limitations of the paper. 


\section{Literature review and hypotheses}

Firms participate in strategic alliances for various reasons (Gulati and Singh, 1998). They might engage in collaborative relationships for developing knowledge, experimenting with assets on an arm's length basis, preserving limited resources and gaining access to markets (Dacin et al., 2007; Hitt et al., 2000). Despite motivations, firms are heterogeneous in their propensity to form alliances. In an attempt to explain such variety, theory has converged on two firm-specific perspectives.

The first perspective is related to the observation that some firms might be less attractive than others as an alliance partner. For instance, resourcebased view (RBV) scholars focus on the role of the resources a firm owns as a predictor of its alliance propensity (Mowery et al., 1998). Accordingly, alliances are considered as means to get access to valuable resources which will generate a competitive advantage (Hitt et al., 2000). Thus, a firm that does not possess resources that can be leveraged to develop managerial skills and capabilities, generate new knowledge or build valuable relationships that might facilitate the counterpart's access to a new markets (Russo and Vurro, 2010), will be considered less attractive as an alliance partner. Other scholars point to the risks associated to the alliance as a deterrent for its formation. In particular, strategic alliances are considered as risky means of corporate development because of exchange related hazards, which are connected to the asymmetry of information in assessing ex-ante firm resources and capabilities, and the risk of moral hazard, which is connected to the cost (or the impossibility) of monitoring a firm's contribution to the alliance (Gulati and Higgins, 2003). Previous work has emphasized that, ceteris paribus, limited or incomplete information when assessing the value of inter-firm collaborations reduce a firm's likelihood to attract potential partners for an alliance (Hoenig and Henkel, 2015). Similarly, it has been found that the lack of trust in the counterpart increases the cost associated with the monitoring of opportunistic behaviors of the parties involved in the alliance (Das and Teng, 1998), reducing firm attractiveness.

The second perspective is related to the observation that some firms might be less able than others in forming and managing alliances. In particular, extant research points to the lack of alliance capability as a key factor that negatively affect a firm's propensity to ally (Wang and Rajagopalan, 2015). In fact, limited abilities to search, negotiate, manage, and terminate an alliance (Kale and Singh, 2007) are associated to a lower propensity of participating into an alliance. For instance, it has been observed that firms not endowed with this capability prefer alternative growth strategies, such as acquisitions or internal development (Villalonga and McGahan, 2005).

Several studies have investigated which factors could mitigate these negative effects. Some scholars have focused on the strategic decisions or on the investments that increase the resource endowment of a firm, which, in turn, might positively affect firm attractiveness as an alliance partner. For instance, it has been found that superior technological knowledge makes a firm more attractive as potential alliance partner, compared to firms with inferior technological knowledge (Ahuja, 2000). Similarly, 
sinergie Vol. 39, Issue 2, 202

having resources that might enable a partner's understanding of nonmarket environments or provide access to decision and opinion makers increases a firm's attractiveness (Lin and Darnall, 2015). Other scholars focus on the aspects that might mitigate the relational risk. For instance, it has been found that the existence of specific inter-organizational ties, such as those with highly reputed business partners or suppliers increase the perceived trust in the firm (Luo, 2007). Similarly, firm status (Stuart, 2000), market identity (Russo et al., 2019), reputation (Stern et al., 2014), and investment to reduce its environmental impact (Norheim-Hansen, 2015) are considered as trust-enhancing mechanisms in the context of alliance formation.

By adopting a capability lens, research has also analyzed what contributes to the emergence of alliance-related skills (Wang and Rajagopalan, 2015). While a firm's previous experience in collaborating via alliances has been identified as one of the most important antecedents of the emergence of this capability, scholars have recently examined the role played by the dedicated alliance function (Russo and Vurro, 2019). This function is an organizational unit that contributes to the codification of the knowledge relative to the alliances and manages the activities that have to be performed (Kale and Singh, 2007). Similarly, it has been observed the existence of a spillover effect on alliance capability from performing activities that show similar features to those of the alliance in terms of knowledge domains, managerial tasks or a/the counterpart's characteristics (Zollo and Reuer, 2010).

\subsection{Sustainability orientation and alliance propensity}

Despite the vast amount of research aimed at identifying which factors may foster or impede a firm's participation in alliances, we argue that a key neglected element that can also influence a firm attractiveness as an alliance partner, as well its ability to form and manage alliances, is a firm's orientation towards sustainability. This orientation is rooted in the development of sustainability strategies consisting of the planning and implementation of corporate activities in response to social and environmental responsibilities. Accordingly, sustainability orientation implies a stronger involvement of stakeholders in the firm's decision making processes and a greater attitude toward long-term value creation (Eccles et al., 2014). As a consequence, sustainability-oriented firms display a greater ability in understanding the stakeholders' needs and expectations (Freeman et al., 2007), which in turn elicits the emergence of relations based on mutual trust (Bridoux and Stoelhorst, 2014) and an increased propensity in measuring and disclosing non-financial information (Cui et al., 2018). Indeed, firms with strong sustainability orientation have been observed to behave differently from others, in terms of the governance structure they adopt to take into account environmental and social issues (Eccles et al., 2014), especially in the context of corporate development activities such as acquisitions (Russo et al., 2018), or innovation (Cheng, 2020). 
We wish to advance this stream of research by submitting that sustainability-oriented firms are also different in terms of attractiveness as an alliance partner, thus resulting in a higher propensity to ally. In particular, four main arguments point to a positive effect of firm orientation toward sustainability on in propensity of forming alliances. The first argument pertains the type and value of the resources and capabilities owned by a sustainability-oriented firms. In fact, sustainability orientation has been indicated as an important driver for the development of innovative capabilities within the firm. On the one hand, by engaging in sustainability firms, they are more aware of a wider set of need of their stakeholders, including social and economic ones (Adams et al., 2016). This results in an increased ability to interpret external stimuli and in the continuous search for solutions that will enable the firm to integrate the stakeholders' needs in the development of product and services (Cheng, 2020). On the other hand, the long term attitude of sustainable firms elicits the creation of relationships based on principles of fairness and mutual trust, which, in turn promote the utilization and dissemination of knowledge within the stakeholder network (Jiang et al., 2019). In particular, the characteristics of the relationships and the continuous interactions between the parties promote the development of a shared perspective and a shared vocabularies between them, which are necessary elements for the transmission of tacit knowledge (Jones et al., 2018). Further, these resources and capabilities are difficult to be imitated by an outside actor because of the complexity and the causal ambiguity related to their formation. The intrinsic characteristics of these resources, such as the complexity in assessing them or the fragility associated to the fact that they have been generated and are embedded within the firm stakeholder network, might increase the likelihood that a potential counterpart will seek them through an alliance (Carayannopoulos and Auster, 2010).

The second argument is rooted in the observation that sustainability orientation might be perceived as a signal of trustworthiness by potential counterparts because of the long-term attitude and expected fairness which emerge from developing an attitude towards stakeholders (Eccles et al., 2014; Zander and Zander, 2005). In this sense, an higher level of sustainability orientation could represent a signal of trustworthiness for the firm possessing it, increasing its attractiveness to external audiences (Parmar et al., 2010). In addition, the firm's sustainability orientation reflects its tendency to build and manage relationships according to the principles of fairness and reciprocal trust (Bridoux and Stoelhorst, 2014). This suggests that if a potential partner makes an "outside-in" analysis to assess the focal firm (i.e. interviewing suppliers, customers, former employees and other stakeholders to collect information) the stakeholders involved in this process will be more likely to provide them with positive feedbacks about the firm under assessment and about its management (Chen et al., 2018). These positive feedbacks, in turn, might positively influence the counterpart's perception about the focal firm trustworthiness, smoothing the negotiation process and increasing the likelihood of alliance formation.

The third argument pertains to the effect of sustainability orientation on information asymmetry. Recent developments in CSR literature indicate
Stefano Romito

Angeloantonio Russo

Clodia Vurro

The impact of sustainability

orientation on firm

propensity to ally 
sinergie Vol. 39, Issue 2, 202

that firms with higher levels of sustainability orientation display lower level of information asymmetry, because of the higher propensity to disclose information about internal processes and outcomes, not only economic but also social and environmental (Cui et al., 2018). Furthermore, devoting attention toward sustainability has been associated to a better social evaluation (King, 2008), which can, in turn, influence a firm's external visibility (Pollock et al., 2010) and the likelihood of it being covered by analysts (Bowers and Prato, 2018). Taken together, these studies indicate that firms with strong sustainability orientation would convey a larger amount of information to external audiences because of their tendency to be transparent and a higher likelihood to be covered by analysist and specialized press. Overall, the increased availability of information can reduce the efforts potential counterparts have made to identify and assess the quality of the firm (Ozmel et al., 2013), increasing its attractiveness as an alliance partner.

The fourth argument relates to the observation that sustainability orientation might increase firm ability to form and manage alliances by contributing to the emergence of alliance capability. It has been argued, in fact, that capabilities related to the development of a sustainability oriented approach, influence corporate development activities (Russo et al., 2018). In particular, it has been argued that the capabilities developed in assessing and managing social and environmental issues might be redeployed in the context of target selection or during the negotiation phase, supporting the focal firm in successfully managing these complex tasks. Similar considerations might apply in the case of alliances. Sustainability-oriented firms might have a higher propensity to form alliances as the capabilities they have developed in the interactions with stakeholders might facilitate the assessment of the counterpart's resources. In addition, sustainability orientation might predispose these firms to cope with situations in which there are higher risks of moral hazard (Lorenzoni and Lipparini, 1999) as firms make extensive use of relational contracts to access internal and external resources (Gibbons and Henderson, 2012). These contracts are more generic and open-ended compared to formalized contracts, which imply a higher risk of moral hazard in the relationships of sustainabilityoriented firms. This may be related to two aspects that influence the firm's alliance propensity: first, it might indicate that sustainability-oriented firms are more prone to cope with situations surrounded by uncertainty and, second, it might signal that firms have developed a capability to manage cooperative relationships under uncertainty (Garcia-Castro and Aguilera, 2015).

Taken together, these arguments point to a higher attractiveness of high sustainability-oriented firms, which depend on the resources owned, the lower perceived exchange hazards such as moral hazard and adverse selection, and stronger relational capabilities. These considerations will result in a higher likelihood of observing alliances that involve sustainability-oriented firms. Thus, we hypothesize:

Hypothesis 1: The more sustainability-oriented a firm is, the greater its tendency to form strategic alliances. 
In our baseline prediction we postulated that the sustainability being involved in alliances, because they are more attractive, they will be perceived at lower risk of adverse selection, they will be considered as more trustworthy, and they will be more comfortable in collaborating. This effect could be mitigated under certain conditions, which posit the need for contextualization. We propose three conditions that have the potential to offset the positive impact of sustainability orientation on alliance formation.

The first mitigating factor we consider is the firm potential for value creation, which represents the external assessment of the value of the resources owned by a firm. The second factor relates to an important governance device external to the firm, i.e., the number of analysts covering a given company. The third, which is an important antecedent of the development of a firm ability to form and manage alliances, is the firm's level of diversification. In the next sections, we discuss how these mechanisms provide useful boundary conditions to our baseline hypothesis about sustainability orientation and its effect on propensity to ally.

\subsubsection{Firm potential value creation}

Tobin's Q is the measure of the market perception about a firm value creation. In particular, this measure represents the market assessment about the value of firm resources (Villalonga, 2004), such as its human capital (Vomberg et al., 2015), its technological knowledge (Bracker and Ramaya, 2011), or its ability to gain consensus from the market and the communities in which it operates (Dorobantu et al., 2017). This variable has often been considered as a proxy for firm value creation (see, for example, Garcia-Castro and Francoeur, 2016; Huselid et al., 1997; Kim and Bettis, 2014). In this sense, the degree to which a firm has resources that contribute to value creation might increase its attractiveness as an alliance partner because partnering with that firm can provide higher payoffs, being them in terms of knowledge creation or in terms of access to resources or to valuable partners (Dyer, 2000; Hitt et al., 2004; Jap, 1999).

This argument suggests that the higher the market assessment of firm value the higher the value attributed to firm resources. Thus, we expect the value creation potential to mitigate the value creation effect of firm sustainability orientation on alliance formation.

Hypothesis 2: Firm value creation potential weakens the positive influence of sustainability orientation on alliance propensity

\subsubsection{Financial analyst coverage}

Financial analysts are key for the correct functioning of financial markets. Given their extensive training in finance and industry-specific knowledge, financial analysts provide valuable information in the form of earnings forecasts and recommendations which are useful to investors, 
Sinergie Vol. 39, Issue 2, 2021

and stakeholders more broadly, in order to assess the financial conditions and prospects of firms (Lang and Lundholm, 1996). Analyst coverage has been shown to alleviate informational frictions in financing policies, making firms better able to obtain external financing from equity markets (Chang et al., 2006). In addition, previous work has documented a positive correlation between the number of analysts following a firm and the likelihood to voluntarily disclosure financial information (Hutton, 2005). As such, the analysts covering a firm act both as information intermediaries and as stimuli for the firms' transparency to the external markets as well as to potential partners.

In this context, we can expect the informational advantage that is associated to firms characterized by a high sustainability orientation to be upper bounded as the benefit deriving from increased information availability decreases marginally when the amount information that are available to an external audience reaches a certain threshold level. For instance, Pollock and Rindova (2003) found that the level of media coverage affect investors' decisions at a diminishing rate because the information conveyed through, and thanks to, the relational bonds with stakeholders becomes increasingly redundant. Thus, we posit:

Hypothesis 3: Financial analysts' coverage weakens the positive influence of sustainability orientation on alliance propensity.

\subsubsection{Firm Diversification}

The first strand of theoretical consideration pertains the firm diversification as a resource enhancing mechanism, which, in turn, might influence a firm's propensity of making alliances (Krammer, 2016). Firms that span several knowledge domains develop superior coordinating routines and combinative capabilities that enable them to harness divergent knowledge streams within their boundaries (Kogut and Zander, 1992). The ability to manage internal diversity also enables the firm to handle and derive advantage from external diversity, i.e. the ability to engage with different types of external actors. Additionally, due to their ability to manage external diversity by engaging with different kinds of alliance partners (representing a potentially wide array of technologies and knowledge streams), firms that span different knowledge domains will be able to better predict and identify combinatorial opportunities that are novel and path-breaking, thereby enhancing the potential benefits that they can realize from knowledge-based alliances (Rosenkopf and Almeida, 2003). In this sense, diversified firms might have a higher ability to form and manage alliances as compared to firms that operate in a single sector.

Thus, we expect the firm diversification to mitigate the positive effect of firm sustainability orientation on alliance formation and hypothesize:

Hypothesis 4: Firm diversification weakens the positive influence of sustainability orientation on alliance propensity 


\subsection{Sample selection and estimation procedure}

The impact of sustainability

orientation on firm

We tested our hypothesis over a sample of US firms in the period 20032017. To build the dataset we initially collected data from the Thomson Reuters Asset 4 database, one of the most comprehensive databases providing data on ESG (Environmental, Social and Governance) factors for over 7,000 public companies from 2002. Asset 4 analysts collect data from several public sources such as annual reports, NGO websites, and stock exchange filings. The data collection process is designed to maximize data quality and comprises automated checks, independent audits, and managerial reviews (Eccles et al., 2014). Asset4 was preferred to other databases used in papers on stakeholder orientation such as the Kinder, Lydenberg, Domini \& Co. (KLD) due to the detail and accuracy of the data which is ensured by rigorous processes of quality check and auditing. This choice follows recent trends in studies on CSR and inter-organizational relationships (Ioannou et al., 2016). The first step in the sampling process was identifying the 2,888 US firms whose ESG performance had been assessed by ASSET4. Second, the Thomson Reuters Securities Data Company (SDC) Platinum database was used to collect data on alliances realized by these companies in the period 1997-20017. This choice follows an established practice in the existing alliance literature (Lavie and Rosenkopf, 2006). Out of the 2,888 ASSET4 US firms, 1,270 have realized at least one alliance in the period 2003-2017, with a total number of 6,516 alliances. This data was used to compute the number of alliances carried out by each firm in each year between 2003 and 2017 and to identify in which years of the analysis period each firm carried out new alliances (if any). The third step in the sampling process was collecting data about control variables for each firm. This was done by using the Thomson Reuters Datastream database. Collected data was then merged with the stakeholder orientation data from ASSET4 and variables related to alliance activity computed based on SDC data. The 6-digit version of the CUSIP identifier was used throughout the entire sampling process as the linking field to merge the three different datasets and identify each firm. The risk of possible discrepancies in CUSIPs was minimized by using databases that all belong to Thomson Reuters (ASSET4, SDC, and Datastream) and should report the same CUSIP for each firm. In addition, manual checks were also performed to ensure accuracy. Finally, we retrieved information about industry concentration from the Hoberg-Philips data library. The final sample was reduced to 10,509 observations due to missing data in Datastream and in the Hoberg-Philips datasets.

To estimate the effect of firm sustainability orientation on the alliance propensity we ran population-averaged regression models and used a generalized estimating equation (GEE) to control for firm heterogeneity. Given the nature of our dependent variable, we used a negative binomial model. In each model, the independent and control variables were lagged by 1 year. This approach follows an established practice in alliance literature to mitigate reverse causality concerns (Russo et al., 2019). 


\section{sinergie}

Vol. 39, Issue 2, 202

\subsection{Dependent Variable}

The dependent variable is the propensity of a firm to form alliances, measured as the number of alliances formed by a firm in a given year (Rothaermel, 2001).

\subsection{Explanatory Variables}

Firm sustainability orientation. To operationalize firm sustainability orientation, we took the Environmental, Social and Governance (ESG) scores assigned by Asset 4 to each firm included in the sample. These scores reflect firm decisions and investments aimed at reaching certain outcomes in terms of social impact, environmental footprint, transparency, and inclusiveness. Following previous research (see, for example, Cheng et al., 2014), we constructed the variable sustainability orientation as an equally weighted average of the environmental, social and governance (ESG) scores for the focal firm for every year in our dataset.

The second explanatory variable is firm value creation potential. To operationalize it, we adopted the firm Tobin's $Q$ which is the ratio of firm market value divided by the book value of its assets. This variable captures a firm's market-based performance, as well as the growth opportunities a firm can access through an alliance or an acquisition of the firm (Deng et al., 2013).

The third explanatory variable is coverage by financial analysts. At firm level, we operationalized this variable as the number of analysts covering a firm in a given year. Since the $\mathrm{I} / \mathrm{B} / \mathrm{E} / \mathrm{S}$ database reports quarterly data, we used the average of the four quarters' figures to obtain a yearly score.

The fourth explanatory variable is firm diversification. To operationalize it, we counted the number of segments (SIC codes) in which the firm operates (Rothaermel, 2001).

\subsection{Control Variables}

Several firm-specific control variables were introduced in the analysis to mitigate concerns for potential heterogeneity at firm level in the tendency to form alliances. We controlled for firm size as previous research has shown its influence on the propensity to form alliances (Beckman et al., 2004). Following an established practice in the alliance literature, this was measured as the log of the number of the employees. We accounted for the effect of previous experiences with alliances using the number of alliances the firm conducted in the previous three years (Alliance experience) (Kale and Singh, 2007). We included firm financial solvency which indicates the financial resources available to support alliance activities, and can reveal organizational slack which in turn can influence its alliance propensity (Lavie and Rosenkopf, 2006; Vurro and Russo, 2009). We operationalized the variable as the debt-to-asset ratio, following previous papers on alliances.

We included the intangible asset ratio which might positively influence the attractiveness of a firm as a partner for alliances (Bizzi, 
2017). We included a control for firm financial performance as it can also have an influence on alliance-related decisions, for instance by facilitating reinforcement of existing routines and discouraging alliance formation (Lavie and Rosenkopf, 2006). This was included as control through earnings per share (EPS). To account for potential heterogeneity based on experience, we included firm age as a control for the analysis, measured as the logarithm of the difference between the focal year and the year in which the firm was founded. Seventh, we included the intensity of competition within the focal firm industry to control for industry dynamics (Caves, 1998). In order to estimate the extent of competition faced by a given firm, we adopted the formulation of the Herfindahl-Hirschman concentration index (HHI) proposed by Hoberg and Phillips according to whom the strength of competition between a pair of firms can be inferred from the degree of similarity with which each describes its products in their annual statements (2010). More specifically, since US public firms are legally required to provide accurate and updated product description in their annual statements, the two scholars rely on a text-based analysis of such descriptions to compute a pairwise similarity matrix - i.e. a matrix of the pairwise similarity score for any two given firms in the sample. Based on the similarity scores, the two scholars construct a Text-Based Industry Classification (TNIC-3) with the same degree of coarseness ${ }^{2}$ as the SIC-3 and calculate the HHI index accordingly. Lastly, we controlled for industry effect using two-digit US Standard Industrial Classification codes (industry dummy variables), for temporal effects (year dummy variables). Table 1 reports the summary statistics and the pairwise correlations.

Tab. 1: Summary statistics and pairwise correlations

\begin{tabular}{|l|l|c|c|c|c|c|c|c|c|}
\hline & \multicolumn{1}{|c|}{ Variable } & Mean & Std Dev & 1 & 2 & 3 & 4 & 5 & 6 \\
\hline 1 & Alliance propensity & 0.376 & 1.295 & & & & & & \\
\hline 2 & Alliance experience & 0.218 & 1.805 & 0.642 & & & & & \\
\hline 3 & Intangible Asset Ratio & 0.225 & 0.212 & 0.041 & 0.013 & & & & \\
\hline 4 & Industry Competition & 0.242 & 0.235 & -0.006 & -0.014 & 0.183 & & & \\
\hline 5 & Age & 0.365 & 1.040 & 0.050 & 0.054 & 0.035 & 0.202 & & \\
\hline 6 & Debt/Asset & 0.266 & 0.212 & -0.015 & -0.021 & 0.149 & 0.003 & 0.010 & \\
\hline 7 & Size & 0.265 & 1.581 & 0.148 & 0.139 & 0.023 & 0.032 & 0.128 & 0.016 \\
\hline 8 & EPS & 2.539 & 5.948 & 0.003 & -0.002 & 0.006 & -0.006 & -0.002 & 0.003 \\
\hline 9 & Sustainability Orientation & 0.066 & 0.997 & 0.170 & 0.178 & -0.011 & 0.114 & 0.309 & -0.055 \\
\hline 10 & Tobin's Q & 1.252 & 1.270 & 0.036 & 0.032 & 0.052 & 0.059 & -0.072 & -0.021 \\
\hline 11 & Analyst & 0.572 & 1.152 & 0.240 & 0.216 & 0.105 & -0.045 & 0.156 & -0.051 \\
\hline 12 & Diversification & 2.773 & 1.503 & 0.048 & 0.041 & -0.053 & 0.066 & 0.253 & -0.016 \\
\hline & Variable & & & 7 & 8 & 9 & 10 & 11 & \\
\hline 8 & EPS & & & 0.004 & & & & & \\
\hline 9 & Sustainability Orientation & & & 0.264 & 0.060 & & & & \\
\hline 10 & Tobin's Q & & & -0.015 & -0.003 & -0.037 & & & \\
\hline 11 & Analyst & & & 0.236 & -0.006 & 0.219 & 0.063 & & \\
\hline 12 & Diversification & & & 0.143 & -0.003 & 0.206 & -0.087 & 0.163 & \\
\hline
\end{tabular}

Source: Our elaboration

2 Coarseness refers to the likelihood that, choosing randomly two firms in the sample, these firms result related according to the proposed classification 


\section{sinergie}

Vol. 39, Issue 2, 202

\section{Results}

Table 2 reports the regression models used to test our hypothesis. Model 1 is the baseline model, including only control variables. Coefficient estimates for the control variables confirm results shown in previous research: alliance experience $(\mathrm{p}=0.000)$, firm size $(\mathrm{p}=0.000)$, and intangible asset ratio $(\mathrm{p}=0.000)$ are all positively correlated with the likelihood of entering into an alliance.

The coefficient estimate for the effect of firm sustainability orientation on the propensity to ally (Model 2) is positive and statistically significant, which provides support for hypothesis 1. In particular, an increase in the firm's stakeholder orientation by one standard deviation is associated to a $1.7 \%$ increase in the alliance propensity $(\mathrm{p}=0.000)$.

Our second hypothesis submitted that the firm potential for value creation mitigates the positive effect of stakeholder orientation on the intensity of alliance activity. In Model 3 we report the coefficient associated to the interaction term between stakeholder orientation and Tobin's $Q$ which is negative and significant $(\mathrm{p}=0.000)$. This result supports hypothesis 2 .

In the third hypothesis, we predicted that the number of financial analysts covering the firm might mitigate the positive effect of firm stakeholder orientation on alliance intensity. Results reported in Model 4 provide support for the hypothesis. In fact, the coefficient estimate for the interaction term is negative and significant $(\mathrm{p}=0.000)$.

Model 5 presents the results of the analyses aimed at testing hypothesis 5 . The interaction between sustainability orientation and firm diversification is positive and not statistically significant $(\mathrm{p}=0.378)$, which does not provide support for the mitigating effect of diversification.

Table 3 presents a set of additional analysis aimed at ensuring the robustness of our main result. In Model 6 we replicated the analyses using a random effect Poisson estimation.

In Model 7, we dichotomized the dependent variable and we estimated the effect of sustainability orientation on alliance likelihood using a random effect Logit estimation, including a control for the sector in which the firm operates (first 2 digits of the firm's primary SIC codes). Results do not differ from those reported in Table 2, confirming our findings. 
Tab. 2: Results of main analyses

\begin{tabular}{|c|c|c|c|c|c|}
\hline \multicolumn{6}{|c|}{ GEE Negative Binomial Estimation } \\
\hline & Model 1 & Model 2 & Model 3 & Model 4 & Model 5 \\
\hline \multirow[t]{2}{*}{ Alliance Experience } & $0.687^{* * *}$ & $0.663^{* * *}$ & $0.657^{* * *}$ & $0.659^{* * *}$ & $0.655^{* * *}$ \\
\hline & $(0.014)$ & $(0.014)$ & $(0.014)$ & $(0.014)$ & $(0.014)$ \\
\hline \multirow[t]{2}{*}{ Intangible asset ratio } & $0.711^{\star * *}$ & $0.708^{\star * *}$ & $0.735^{\star * *}$ & $0.651^{* * *}$ & $0.711^{\star * *}$ \\
\hline & $(0.118)$ & $(0.118)$ & $(0.119)$ & $(0.119)$ & $(0.117)$ \\
\hline \multirow[t]{2}{*}{ HHI } & -0.031 & -0.033 & -0.090 & -0.047 & -0.044 \\
\hline & $(0.111)$ & $(0.110)$ & $(0.112)$ & $(0.111)$ & $(0.110)$ \\
\hline \multirow[t]{2}{*}{ Age } & 0.011 & -0.039 & -0.035 & -0.040 & -0.029 \\
\hline & $(0.029)$ & $(0.030)$ & $(0.031)$ & $(0.031)$ & $(0.030)$ \\
\hline \multirow[t]{2}{*}{ Debt Asset } & -0.057 & -0.044 & 0.025 & -0.028 & -0.026 \\
\hline & $(0.118)$ & $(0.123)$ & $(0.122)$ & $(0.121)$ & $(0.121)$ \\
\hline \multirow[t]{2}{*}{ Size } & $0.037^{* * *}$ & $0.018^{*}$ & 0.017 & $0.021^{*}$ & 0.014 \\
\hline & $(0.012)$ & $(0.011)$ & $(0.011)$ & $(0.011)$ & $(0.011)$ \\
\hline \multirow[t]{2}{*}{ EPS } & -0.006 & $-0.012^{*}$ & -0.010 & $-0.014^{*}$ & $-0.012^{*}$ \\
\hline & $(0.005)$ & $(0.007)$ & $(0.007)$ & $(0.008)$ & $(0.007)$ \\
\hline \multirow[t]{2}{*}{ Sustainability Orientation } & & $0.166^{* * *}$ & $0.274^{* * *}$ & $0.220^{* * *}$ & 0.012 \\
\hline & & $(0.026)$ & $(0.033)$ & $(0.027)$ & $(0.051)$ \\
\hline \multirow[t]{2}{*}{ Tobin's Q } & & & $0.031^{*}$ & & \\
\hline & & & $(0.019)$ & & \\
\hline \multirow[t]{2}{*}{ Sustainability Orientation ${ }^{*}$ Tobin’s Q } & & & $-0.069^{* * *}$ & & \\
\hline & & & $(0.017)$ & & \\
\hline \multirow[t]{2}{*}{ Analyst } & & & & $0.059^{* *}$ & \\
\hline & & & & $(0.024)$ & \\
\hline \multirow[t]{2}{*}{ Sustainability Orientation ${ }^{\star}$ Analyst } & & & & $-0.088^{\star * *}$ & \\
\hline & & & & $(0.017)$ & \\
\hline \multirow[t]{2}{*}{ Diversification } & & & & & -0.060 \\
\hline & & & & & $(0.022)$ \\
\hline \multirow[t]{2}{*}{ Sustainability Orientation ${ }^{\star}$ Diversification } & & & & & -0.107 \\
\hline & & & & & $(0.22838)$ \\
\hline \multirow[t]{2}{*}{ Constant } & $-1.926^{* * *}$ & $-1.794^{\star * *}$ & $-1.825^{* * *}$ & $-1.918^{* * *}$ & $-1.634^{* * *}$ \\
\hline & $(0.125)$ & $(0.122)$ & $(0.124)$ & $(0.147)$ & $(0.134)$ \\
\hline Year & YES & YES & YES & YES & YES \\
\hline Observations & 10,509 & 10,509 & 10,339 & 10,509 & 10,509 \\
\hline Number of firms & 2,056 & 2,056 & 2,016 & 2,056 & 2,056 \\
\hline Chi-Squared & $3,131.06$ & $3,217.11$ & $3,192.59$ & $3,244.24$ & $3,241.46$ \\
\hline Prob $>$ Chi Squared & 0 & 0 & 0 & 0 & 0 \\
\hline
\end{tabular}

Source: our elaboration
Stefano Romito Angeloantonio Russo

Clodia Vurro

The impact of sustainability

orientation on firm propensity to ally 
sinergie

Vol. 39, Issue 2, 202
Tab. 3: Robustness tests

\begin{tabular}{|c|c|c|}
\hline & $\begin{array}{c}\text { Model } 6 \\
\text { Random effect } \\
\text { Poisson } \\
\end{array}$ & $\begin{array}{c}\text { Model } 7 \\
\text { Random effect } \\
\text { Logit } \\
\end{array}$ \\
\hline \multirow[t]{2}{*}{ Alliance Experience } & $0.100^{* *}$ & $2.475^{* * *}$ \\
\hline & $(0.051)$ & $(0.120)$ \\
\hline \multirow[t]{2}{*}{ Intangible asset ratio } & $1.061^{* * *}$ & 0.258 \\
\hline & $(0.174)$ & $(0.170)$ \\
\hline \multirow[t]{2}{*}{$\mathrm{HHI}$} & -0.060 & $-0.340^{* \star}$ \\
\hline & $(0.169)$ & $(0.149)$ \\
\hline \multirow[t]{2}{*}{ Age } & $-0.119^{\star \star \star}$ & $0.058^{*}$ \\
\hline & $(0.042)$ & $(0.032)$ \\
\hline \multirow[t]{2}{*}{ Debt Asset } & -0.086 & 0.027 \\
\hline & $(0.149)$ & $(0.156)$ \\
\hline \multirow[t]{2}{*}{ Size } & $0.230^{* * *}$ & 0.017 \\
\hline & $(0.082)$ & $(0.017)$ \\
\hline \multirow[t]{2}{*}{ EPS } & -0.007 & -0.005 \\
\hline & $(0.011)$ & $(0.009)$ \\
\hline \multirow[t]{2}{*}{ Sustainability Orientation } & $0.249^{* * *}$ & $0.073^{\star}$ \\
\hline & $(0.064)$ & $(0.038)$ \\
\hline \multirow[t]{2}{*}{ Constant } & $-1.926^{\star * *}$ & $-1.794^{\star * *}$ \\
\hline & $(0.125)$ & $(0.122)$ \\
\hline Year & YES & YES \\
\hline Sector & NO & YES \\
\hline Observations & 10,509 & 10,509 \\
\hline Number of firms & 2,056 & 2,056 \\
\hline Chi-Squared & $3,131.06$ & $3,217.11$ \\
\hline Prob $>$ Chi Squared & 0 & 0 \\
\hline
\end{tabular}

Source: our elaboration

\section{Discussion and conclusion}

In this paper, we analyzed the influence of sustainability orientation on firm alliance propensity. Our results show that firm sustainability orientation positively influences its propensity to ally. We theorized that this relationship is attributable to the fact that sustainability-oriented firms are perceived as more attractive as an alliance partner, because of the resources they own and the lower relational risk they convey. Moreover, we predicted that these firms display a higher ability to form and manage alliances, because of the development of relational capabilities.

We showed that sustainability orientation particularly matters for firms that present characteristics that are commonly associated to lower attractiveness as an alliance partner. In particular, when the financial market does not acknowledge to the focal firm a potential for future value creation, the relational resources the firm has developed by collaborating with its stakeholders in the mainframe of corporate sustainability, still represent a source of valuable knowledge for potential partners. Further, in case of 
limited external information to assess potential partners, the sustainability orientation is associated with a lower perceived risk of adverse selection.

By bridging literature on the drivers of partner selection in strategic alliances and sustainability orientation, this paper makes contributions to two distinct streams of research. First, we advance our understanding of the antecedents of alliance formation by introducing the role of sustainability orientation. We extend alliance research that has examined, through different theoretical lenses, the factors that affect firm attractiveness in the alliance context, by theorizing on how a firm sustainability orientation shapes firm propensity to ally. Our arguments and findings, therefore, emphasize the critical role played by the way in which the firm integrates sustainability into its strategic decision-making processes, in addition to the considerations about the role of entrepreneurial or market orientation emphasized in previous research. Second, we contribute to the corporate sustainability literature. In particular we advance existing knowledge on the relationship between sustainability orientation and corporate development activities (Cheng, 2020; Russo et al., 2018). Obtaining a deeper understanding of the benefits of a sustainability-oriented approach, in fact, remains fundamental to encourage managers to increase the integration of sustainability in their decision making. In the alliance context, as discussed in this paper, managers have several incentives to adopt a sustainabilityoriented approach, as this approach can provide them with capabilities, routines and social capital which facilitate alliance formation, knowledge exchange and alliance management. More efforts are needed in this research area, since resulting insights could equip managers with a more profound knowledge of the mechanisms underlying alliance formation, partner selection and alliance management, improving their alliance capabilities and incentivizing them to adopt sustainability-oriented behavior.

Our work represents an initial attempt to investigate the role of firm sustainability orientation in explaining alliance propensity. In so doing, we adopted a firm level perspective assuming that the counterparts are homogeneous. Relaxing this assumption and analyzing the effect similarity\} dissimilarity in partners sustainability orientation on alliance formation might contribute significantly to advance our understanding of the relation between stakeholder orientation and alliance behavior.

Additionally, future research should examine the potential effects of sustainability orientation on alliance performance, which have only been supposed. In fact, sustainability orientation is likely to have a relevant influence also on the management of alliances and, in turn, on their performance, as hypothesized in the previous section. This can happen, for instance, by influencing the development of firm capabilities and social capital, which can have an important impact on alliance management. Third, studies about the relationship between sustainability orientation and types of alliances might be integrated more deeply with concepts and theories from the exploration-exploitation alliance literature, like the balancing of exploration and exploitation across dimensions, time and organizational modes. 


\section{sinergie}

Vol. 39, Issue 2, 202

\section{References}

ADAMS R., JEANRENAUD S., BESSANT J., DENYER D., OVERY P. (2016), "Sustainability-Oriented Innovation: A Systematic Review", International Journal of Management Reviews, vol. 18, n. 2, pp. 180-205.

AHUJA G. (2000), "Collaboration Networks, Structural Holes and Innovation: A Longitudinal Study", Administrative Science Quarterly, vol. 45, n. 3, pp. 425-455.

BECKMAN C.M., HAUNSCHILD P.R., PHILLIPS D.J. (2004), "Friends or Strangers? Firm-Specific Uncertainty, Market Uncertainty, and Network Partner Selection", Organization Science, vol. 15, n. 3, pp. 259-275.

BIZZI L. (2017), “The Strategic Role of Financial Slack on Alliance Formation", Management Decision, vol. 55, n. 2, pp. 383-399.

BOWERS A., PRATO M. (2018), “The Structural Origins of Unearned Status: How Arbitrary Changes in Categories Affect Status Position and Market Impact", Administrative Science Quarterly, vol. 63, n. 3, pp. 668-699.

BRACKER K., RAMAYA K. (2011), "Examining the Impact of Research and Development Expenditures on Tobin's Q", Academy of Strategic Management Journal, vol. 10, pp. 63.

BRIDOUX F., STOELHORST J.W. (2014), "Microfoundations for Stakeholder Theory: Managing Stakeholders with Heterogeneous Motives", Strategic Management Journal, vol. 35, n. 1, pp. 107-125.

CARAYANNOPOULOS S., AUSTER E.R. (2010), "External Knowledge Sourcing in Biotechnology through Acquisition Versus Alliance: A Kbv Approach", Research Policy, vol. 39, n. 2, pp. 254-267.

CAVES R.E. (1998), "Industrial Organization and New Findings on the Turnover and Mobility of Firms", Journal of Economic Literature, vol. 36, n. 4, pp. 1947-1982.

CHANG X., DASGUPTA S., HILARY G. (2006), “Analyst Coverage and Financing Decisions”, The Journal of Finance, vol. 61, n. 6, pp. 3009-3048.

CHEN Z., KALE P., HOSKISSON R.E. (2018), “Geographic Overlap and Acquisition Pairing”, Strategic Management Journal, vol. 39, n. 2, pp. 329-355.

CHENG B., IOANNOU I., SERAFEIM G. (2014), "Corporate Social Responsibility and Access to Finance", Strategic Management Journal, vol. 35, n. 1, pp. 1-23.

CHENG C.C. (2020), "Sustainability Orientation, Green Supplier Involvement, and Green Innovation Performance: Evidence from Diversifying Green Entrants", Journal of Business Ethics, vol. 161, n. 2, pp. 393-414.

CHO S.Y., LEE C., PFEIFFER JR R.J. (2013), "Corporate Social Responsibility Performance and Information Asymmetry", Journal of Accounting and Public Policy, vol. 32, n. 1, pp. 71-83.

CUI J., JO H., NA H. (2018), "Does Corporate Social Responsibility Affect Information Asymmetry?", Journal of Business Ethics, vol. 148, n. 3, pp. 549-572.

DACIN M.T., OLIVER C., ROY J.P. (2007), “The Legitimacy of Strategic Alliances: An Institutional Perspective”, Strategic Management Journal, vol. 28, n. 2, pp. 169-187.

DAS T.K., TENG B.-S. (1998), "Between Trust and Control: Developing Confidence in Partner Cooperation in Alliances", Academy of Management Review, vol. 23, n. 3, pp. 491-512. 
DENG X., KANG J.-K., LOW B.S. (2013), "Corporate Social Responsibility and Stakeholder Value Maximization: Evidence from Mergers", Journal of financial Economics, vol. 110, n. 1, pp. 87-109.

DOROBANTU S., HENISZ W.J., NARTEY L. (2017), "Not All Sparks Light a Fire: Stakeholder and Shareholder Reactions to Critical Events in Contested Markets", Administrative Science Quarterly, vol. 62, n. 3, pp. 561-597.

DYER J.H. (2000), Collaborative Advantage: Winning through Extended Enterprise Supplier Networks, Oxford University Press.

ECCLES R.G., IOANNOU I., SERAFEIM G. (2014), "The Impact of Corporate Sustainability on Organizational Processes and Performance", Management Science, vol. 60, n. 11, pp. 2835-2857.

FREEMAN E.R., MARTIN K., PARMAR B. (2007), "Stakeholder Capitalism", Journal of Business Ethics, vol. 74, n. 4, pp. 303-314.

GARCIA-CASTRO R., AGUILERA R.V. (2015), "Incremental Value Creation and Appropriation in a World with Multiple Stakeholders", Strategic Management Journal, vol. 36, n. 1, pp. 137-147.

GARCIA-CASTRO R., FRANCOEUR C. (2016), "When More Is Not Better: Complementarities, Costs and Contingencies in Stakeholder Management", Strategic Management Journal, vol. 37, n. 2, pp. 406-424.

GIBBONS R., HENDERSON R. (2012), "Relational Contracts and Organizational Capabilities", Organization Science, vol. 23, n. 5, pp. 1350-1364.

GULATI R., HIGGINS M.C. (2003), "Which Ties Matter When? The Contingent Effects of Interorganizational Partnerships on Ipo Success", Strategic Management Journal, vol. 24, n. 2, pp. 127-144.

GULATI R., SINGH H. (1998), "The Architecture of Cooperation: Managing Coordination Costs and Appropriation Concerns in Strategic Alliances", Administrative Science Quarterly, pp. 781-814.

HITT M.A., AHLSTROM D., DACIN M.T., LEVITAS E., SVOBODINA L. (2004), "The Institutional Effects on Strategic Alliance Partner Selection in Transition Economies: China Vs. Russia", Organization Science, vol. 15, n. 2, pp. 173-185.

HITT M.A., DACIN M.T., LEVITAS E., ARREGLE J.-L., BORZA A. (2000), "Partner Selection in Emerging and Developed Market Contexts: ResourceBased and Organizational Learning Perspectives", Academy of Management Journal, vol. 43, n. 3, pp. 449-467.

HOBERG G., PHILLIPS G. (2010), "Product Market Synergies and Competition in Mergers and Acquisitions: A Text-Based Analysis", The Review of Financial Studies, vol. 23, n. 10, pp. 3773-3811.

HOENIG D., HENKEL J. (2015), "Quality Signals? The Role of Patents, Alliances, and Team Experience in Venture Capital Financing", Research Policy, vol. 44, n. 5, pp. 1049-1064.

HUSELID M.A., JACKSON S.E., SCHULER R.S. (1997), “Technical and Strategic Human Resources Management Effectiveness as Determinants of Firm Performance", Academy of Management Journal, vol. 40, n. 1, pp. 171-188.

HUTTON A.P. (2005), "Determinants of Managerial Earnings Guidance Prior to Regulation Fair Disclosure and Bias in Analysts' Earnings Forecasts", Contemporary Accounting Research, vol. 22, n. 4, pp. 867-914.

IOANNOU I., LI S.X., SERAFEIM G. (2016), "The Effect of Target Difficulty on Target Completion: The Case of Reducing Carbon Emissions", The Accounting Review, vol. 91, n. 5, pp. 1467-1492.
Stefano Romito

Angeloantonio Russo

Clodia Vurro

The impact of sustainability

orientation on firm

propensity to ally 
sinergie Vol. 39, Issue 2, 202

JAP S.D. (1999), "Pie-Expansion Efforts: Collaboration Processes in Buyer-Supplier Relationships”, Journal of Marketing Research, vol. 36, n. 4, pp. 461-475.

JIANG W., WANG A.X., ZHOU K.Z., ZHANG C. (2019), "Stakeholder Relationship Capability and Firm Innovation: A Contingent Analysis", Journal of Business Ethics, pp. 1-15.

JONES T.M., HARRISON J.S., FELPS W. (2018), "How Applying Instrumental Stakeholder Theory Can Provide Sustainable Competitive Advantage", Academy of Management Review, vol. 43, n. 3, pp. 371-391.

KALE P., SINGH H. (2007), "Building Firm Capabilities through Learning: The Role of the Alliance Learning Process in Alliance Capability and FirmLevel Success", Strategic Management Journal, vol. 28, n. 1, pp. 981-1000.

KIM C., BETTIS R.A. (2014), "Cash Is Surprisingly Valuable as a Strategic Asset", Strategic Management Journal, vol. 35, n. 13, pp. 2053-2063.

KING B.G. (2008), "A Political Mediation Model of Corporate Response to Social Movement Activism", Administrative Science Quarterly, vol. 53, n. 3, pp. 395-421.

KOGUT B., ZANDER U. (1992), "Knowledge of the Firm, Combinative Capabilities, and the Replication of Technology", Organization Science, vol. 3, n. 3, pp. 383-397.

KRAMMER S.M. (2016), "The Role of Diversification Profiles and Dyadic Characteristics in the Formation of Technological Alliances: Differences between Exploitation and Exploration in a Low-Tech Industry", Research Policy, vol. 45, n. 2, pp. 517-532.

LANG M.H., LUNDHOLM R.J. (1996), "Corporate Disclosure Policy and Analyst Behavior”, Accounting Review, vol. 71, n. 4, pp. 467-492.

LAVIE D., ROSENKOPF L. (2006), "Balancing Exploration and Exploitation in Alliance Formation", Academy of Management Journal, vol. 49, n. 4, pp. 797-818.

LIN H., DARNALL N. (2015), "Strategic Alliance Formation and Structural Configuration", Journal of Business Ethics, vol. 127, n. 3, pp. 549-564.

LORENZONI G., LIPPARINI A. (1999), “The Leveraging of Interfirm Relationships as a Distinctive Organizational Capability: A Longitudinal Study”, Strategic Management Journal, vol. 20, n. 4, pp. 317-338.

LUO Y. (2007), "The Independent and Interactive Roles of Procedural, Distributive, and Interactional Justice in Strategic Alliances", Academy of Management Journal, vol. 50, n. 3, pp. 644-664.

MOWERY D.C., OXLEY J.E., SILVERMAN B.S. (1998), “Technological Overlap and Interfirm Cooperation: Implications for the Resource-Based View of the Firm", Research Policy, vol. 27, n. 5, pp. 507-523.

NORHEIM-HANSEN A. (2015), "Are 'Green Brides' More Attractive? An Empirical Examination of How Prospective Partners' Environmental Reputation Affects the Trust-Based Mechanism in Alliance Formation", Journal of Business Ethics, vol. 132, n. 4, pp. 813-830.

OZMEL U., REUER J.J., GULATI R. (2013), “Signals across Multiple Networks: How Venture Capital and Alliance Networks Affect Interorganizational Collaboration", Academy of Management Journal, vol. 56, n. 3, pp. 852-866.

PARMAR B.L., FREEMAN R.E., HARRISON J.S., WICKS A.C., PURNELL L., DE COLLE S. (2010), "Stakeholder Theory: The State of the Art", The Academy of Management Annals, vol. 4, n. 1, pp. 403-445. 
POLLOCK T.G., CHEN G., JACKSON E.M., HAMBRICK D.C. (2010), “How Much Prestige Is Enough? Assessing the Value of Multiple Types of HighStatus Affiliates for Young Firms", Journal of Business Venturing, vol. 25, n. 1, pp. 6-23.

POLLOCK T.G., RINDOVA V.P. (2003), "Media Legitimation Effects in the Market for Initial Public Offerings", Academy of Management Journal, vol. 46, n. 5, pp. 631-642.

ROSENKOPF L., ALMEIDA P. (2003), "Overcoming Local Search through Alliances and Mobility”, Management Science, vol. 49, n. 6, pp. 751-766.

ROTHAERMEL F.T. (2001), "Incumbent's Advantage through Exploiting Complementary Assets Via Interfirm Cooperation”, Strategic Management Journal, vol. 22, n. 6-7, pp. 687-699.

ROXAS B., COETZER A. (2012), "Institutional Environment, Managerial Attitudes and Environmental Sustainability Orientation of Small Firms", Journal of Business Ethics, vol. 111, n. 4, pp. 461-476.

RUSSO A., VASTOLA V., VURRO C. (2018), "To Be or Not to Be Sustainable? Solving the Dilemma During the Acquisition Process", Sinergie Italian Journal of Management, vol. 36, n. 106, pp.127-140.

RUSSO A., VURRO C. (2010), "Cross-Boundary Ambidexterity: Balancing Exploration and Exploitation in the Fuel Cell Industry", European Management Review, vol. 7, n. 1, pp. 30-45.

RUSSO A., VURRO C. (2019), "Alliance Management Knowledge and Alliance Performance: Unveiling the Moderating Role of the Dedicated Alliance Function", Industrial and Corporate Change, vol. 28, n. 4, pp. 725-752.

RUSSO A., VURRO C., NAG R. (2019), “To Have or to Be? The Interplay between Knowledge Structure and Market Identity in Knowledge-Based Alliance Formation”, Research Policy, vol. 48, n. 3, pp. 571-583.

STERN I., DUKERICH J.M., ZAJAC E. (2014), "Unmixed Signals: How Reputation and Status Affect Alliance Formation", Strategic Management Journal, vol. 35 , n. 4 , pp. 512-531.

STUART T.E. (2000), "Interorganizational Alliances and the Performance of Firms: A Study of Growth and Innovation Rates in a High-Technology Industry", Strategic Management Journal, vol. 21, n. 8, pp. 791-811.

VILLALONGA B. (2004), "Intangible Resources, Tobin'sq, and Sustainability of Performance Differences", Journal of Economic Behavior and Organization, vol. 54, n. 2, pp. 205-230.

VILLALONGA B., MCGAHAN A.M. (2005), “The Choice among Acquisitions, Alliances, and Divestitures", Strategic Management Journal, vol. 26, n. 13, pp. 1183-1208.

VOMBERG A., HOMBURG C., BORNEMANN T. (2015), “Talented People and Strong Brands: The Contribution of Human Capital and Brand Equity to Firm Value", Strategic Management Journal, vol. 36, n. 13, pp. 2122-2131.

VURRO C., RUSSO A. (2009), "Balancing Exploration and Exploitation across Firm Boundaries: Intra- and Interorganizational Learning in the Fuel Cell Industry", in Pogutz S., Russo A., Migliavacca P.O., Innovation, Markets and Sustainable Energy: The Challenge of Hydrogen and Fuel Cells, Edward Elgar Publishing, Cheltenham, UK.

WANG Y., RAJAGOPALAN N. (2015), "Alliance Capabilities: Review and Research Agenda”, Journal of Management, vol. 41, n. 1, pp. 236-260.
Stefano Romito

Angeloantonio Russo

Clodia Vurro

The impact of sustainability

orientation on firm propensity to ally

( 
sinergie Vol. 39, Issue 2, 202

ZANDER I., ZANDER U. (2005), “The inside Track: On the Important (but Neglected) Role of Customers in the Resource-Based View of Strategy and Firm Growth", Journal of Management Studies, vol. 42, n. 8, pp. 1519-1548.

ZOLLO M., REUER J.J. (2010), "Experience Spillovers across Corporate Development Activities", Organization Science, vol. 21, n. 6, pp. 1195-1212. ZOLLO M., REUER J.J., SINGH H. (2002), "Interorganizational Routines and Performance in Strategic Alliances", Organization Science, vol. 13, n. 6, pp. 701-713.

\section{Academic or professional position and contacts}

\section{Stefano Romito}

Post-doc researcher of Management

University of Milan - Italy

e-mail: stefano.romito@unimi.it

\section{Angeloantonio Russo}

Full Professor of Management

LUM University - Italy

e-mail: russo@lum.it

\section{Clodia Vurro}

Associate Professor of Management

University of Milan - Italy

e-mail: clodia.vurro@unimi.it

sinergie italian journal of management

ISSN 0393-5108 DOI $10.7433 / \mathrm{s} 115.2021 .03$
pp. $37-56$ 